\title{
Statistical comparison related to service and reception of the volleyball team CSM Volei Alba Blaj in the CEV Champions League Final Four 2018
}

\author{
Ioan Sabin SOPA ${ }^{1}$, Dan Alexandru SZABO²
}

\begin{abstract}
Background: Volleyball game has developed and spread all over the world being more and more spectacular and dynamic. The importance of an objective analysis of the game has become decisive for obtaining the victory, and the statistical analysis of the specific parameters such as serve receiving, serves, points obtained, blocks can influence the results of the game.

Aim: The purpose of the experiment was to analyze the decisive factors in the success or failure of the CSM Volleyball team Volei Alba Blaj in the Final Four CEV Champions League for women's volleyball.

Methods: The statistical analysis included descriptive statistics elements (mean, median, standard deviation), and elements of inferential statistics. The D'Agostino \& Pearson test was applied to determine the distribution of the analyzed data series. For the comparison of means and medians the t-Student test was applied, for pair data, and the Wilcoxon test, respectively. The significance threshold chosen for the p value was 0.05. The statistical analysis was performed using the Graph Pad Prism utility. Results: We compared the two main parameters in the first phase of the volleyball game that consisted of service and service reception. The results were significant regarding the service parameter, where we compared the total number of good serves, serve errors and ace serves. Then, we have also analyzed the second parameter found in the first phase of the volleyball game, the serve reception. The results were also statistically significant showing that both parameters, service and service reception, are decisive in the volleyball game.

Conclusions: The statistical analysis in the volleyball game can emphasize objective and decisive factors and parameters that can influence the result of a volleyball game. It is important to use statistics in modern volleyball game and to prepare the game or even action in real time so as to obtain the best results.
\end{abstract}

Key words: statistics, volleyball, tactical analyze in sports.

\section{Rezumat}

Fundamentare: Jocul de volei s-a dezvoltat și răspândit peste tot în lume devenind din ce în ce mai spectaculos şi dinamic. Importanţa unei analize obiective a jocului începe să fie decisivă pentru a obţine victoria, analiza statistică a unor parametrii specifici ca de exemplu preluarea din serviciu, serviciul, puncte obţinute, blocaje realizate, pot influența rezultatul unui joc. Obiective: Scopul acestui experiment a fost să analizăm factorii decisive în succesul sau insuccesul echipei de volei CSM Volei Alba Blaj în cadrul Turneului Final CEV Champions League - volei feminin.

Metode de cercetare: Analiza statistică a inclus elemente descriptive de statistică (media, mediana şi abaterea standard) şi elemente de statistică interferenţială. Testul D’Agostino \& Pearson au fost aplicate, pentru date pereche, respectiv Testul Wilcoxon. Pragul de semnificație ales pentru valoarea lui p a fost de 0.05 . Analiza statistică a fost efectuată folosind programul Graph Pad Prism.

Rezultate: Am comparat cei doi parametri importanţi în structura de joc numarul unu care conţine serviciul şi preluarea din serviciu. Rezultatele au fost semnificative in ceea ce privește parametrul serviciu în care am comparat numărul total de servicii bune, erorile de serviciu şi serviciul as. Ulterior am analizat şi cel de-al doilea parametru aparţinând primei structure de joc în volei, preluarea din serviciu. Rezultatele au fost de asemenea semnificative statistic aratând că ambi parametri, serviciul şi preluarea din serviciu sunt decisive în jocul de volei.

\footnotetext{
${ }^{1}$ Lecturer PhD, “Lucian Blaga” University, Department of Environmental Science, Physics, Physical Education and Sport Sibiu Romania, $e$ mail:sopasabin@yahoo.com

2 Assistant PhD, "George Emil Palade" University of Medicine, Pharmacy, Science, and Technology of Targu Mures, Romania, e-mail danalexandru.szabo@umfst.ro
} 
Concluzii: Analiza statistică în jocul de volei poate sublinia obiectiv factorii şi parametri decisivi care pot influenţa rezultatul unui joc de volei. Este importantă utiziarea programelor statistice în jocul de volei modern şi pregătirea jocului sau chiar acţionarea în timp real pentru obţinerea celor mai bune rezultate.

Cuvinte cheie: statistică, volei, analiză tactică în sport. 


\section{Introduction}

Volleyball has become one of the most practiced sports in the world. The game of volleyball requires expertise in several physical fitness and performance areas [1].

Volleyball is a sport in which $76.6 \%$ of rallies last 12 seconds or less, and the average rally time is approximately 11 seconds [2]. The range of durations includes rallies as short as 3 seconds and as long as 40 seconds. In addition, $44 \%$ of rest periods between rallies are 12 seconds or less, with the average rest time being of 14 seconds [3].

During those rallies, volleyball players perform different activities such as jumps, drops, multidirectional accelerations, quick changes of directions, stops and landings. Players at different positions (setter, opposite hitter, passer-hitter, middle blocker and libero player) use various movement patterns with different frequencies during a competition. The game of volleyball should proceed from simple to complex techniques, tactics and strategies [4].

The volleyball game requires expertise in more motor skills, and performance often depends on an individual's ability to jump and land [5].

Service performance affects the balance between service and reception. In high-performance volleyball, this balance is inclined to the reception. Thus, $62.0 \%-72.6 \%$ of receptions are perfect in men's volleyball (allowing the game coordinator to hold all the variants in the attack), and 53.0\%-70.5\% are excellent in women's volleyball [6] [7]. These values are higher than those found in men's volleyball to guarantee the success of the service (4.4\%-6.8\%), as well as women's volleyball $(3.3 \%-$ $5.0 \%$ [6] [8]. This imbalance in the effectiveness of reception compared with the effectiveness of service is, in part, the foundation of success for the first game structure [9].

The consulted studies of international literature, show the following speed service values: topspin jump of $85.3 \mathrm{~km} / \mathrm{h}$ [10], $91.4 \mathrm{~km} / \mathrm{h}$ [11] and 82.9 $\mathrm{km} / \mathrm{h}$ and "float" service of 41-43 km/h in boys [12] and $47.52 \mathrm{~km} / \mathrm{h}$ in girls [13].

According to a recent study from 2014, the characteristics of the service in the males are: service from foot $(7.1 \%$ of total services) performed at a speed of 42.0 - $55.0 \mathrm{~km} / \mathrm{h}$, "float" jump service (40.7 $\%$ of total services) done at a speed of 40.0-75.0 $\mathrm{km} / \mathrm{h}$, and topspin jump service $(52.2 \%$ of all services) conducted at a speed of $73.0-104.0 \mathrm{~km} / \mathrm{h}$. The service features in the female game are: service from foot (45.9\% of all services) performed at a speed of $43.0-61.0 \mathrm{~km} / \mathrm{h}$, float jump service $(37.5 \%$ of the total services) at a speed of $40.0-61.0 \mathrm{~km} / \mathrm{h}$, and topspin jump service (16.6\% of all services) carried out at a speed of $66.0-89.0 \mathrm{~km} / \mathrm{h}$ [14].

Volleyball is a sport characterized by high-intensity motor actions and a short duration of the motor actions (jumping, attack, and blocking), followed by periods of reduced physical effort. These measures are influenced by the efficiency of anaerobic metabolism, having an aerobic metabolism that contributes to maintaining physical performance and post-effort recovery [15] [16].

Several studies show that high-performance volleyball athletes have much better physical and anthropometric fitness than lower volleyball athletes [17]. Therefore, volleyball requires a physical condition at the highest level, which complements tactical and technical performance.

To maximize the adaptive responses and performance of athletes, volleyball teams implement other physical training models based on courtspecific movement, especially during precompetitive periods. Among the systems used, resistance training is recognized as an effective method for developing neuromuscular capacity, which increases competitive performance. Handling the intensity variables during strength training (intensity, volume, breaks, etc.) and their distribution over time allows the development of physical capabilities such as endurance, maximum strength, and strength [18].

Starting from the premise that "the evolution of the contemporary society generates an unprecedented quantitative growth and qualitative development, in all fields, including the one of performance sport, the immediate preparation for the competition implies the setting of objectives that will lead to maximizing the capacity to mobilize the biological, motor and psychological potential of the athlete" [19] by capitalizing on the current level of knowledge in the field. Thus, it is justified why "the level reached today by the development of sports practice, like any activity with interdisciplinary characteristics, is permanently subject to a dynamic alert, leaving aside techniques and means with which to act in training, 
due to the fact that they no longer correspond today to the high performance requirements" [20].

The use of computer science in sports games comes to add value by ensuring [21]:

- feedback information on game evaluation and analysis;

- setting up databases on tactical analysis, global or team-specific game systems, allowing action on training to change strategies; the analysis can be extended to the opposing teams in order to adopt strategies that will allow the confrontation of these teams, thus reducing the degree of uncertainty;

- analysis of the technical-tactical behavior of the players taken individually, in order to be able to intervene in training sessions, either on their executions or on the tactical decisions;

- analysis of the energetic impact of the game actions so that the conduct of the training allows the observance of the specific constraints of the situation in the game;

The performance in the collective sports game is mirrored by a series of inter-relational components, located in the middle of a complex universe where there is a diversity of phenomena expressed through general and specific systemic relations, which act synergistically to obtain the sports performances [22].

The research and analysis of the components that determine a sports performance represent complex operations, due to the increased number of variables involved in a sports gesture no matter how simple it is [23].

If we are to deal with the concept of multimedia, which has an increasingly important role in the game of volleyball, we can define it as "the handling capacity (obtaining, processing, storage, transfer, presentation), in an integrated numerical form of the information, represented by several means (English 'media'), of which at least one is continuous (periodically, time-dependent) and one is discrete (asynchronous, independent of time)" [24].

This concept is based on the possibilities offered by the computing technique to simultaneously store and process information of different types, including video images, in increasing quantities and in real time. In this context, multimedia defines the possibility of the computing technique to use at least two information paths $($ media $=$ path) in parallel: static or dynamic images + sound + textual explanations + graphical analysis, etc. [25] or "a set of software and hardware, capable of using, at the same time, media sources, such as film, video, music, combined with text and numbers, simulations and electronic communications, etc." [26].

In volleyball, both observation-based analysis and match analysis allow researchers to characterize a wide variety of technical procedures in different circumstantial contexts. The tactical principles of these procedures not only strengthen the collective structure of any volleyball team, [27] but they are also important for optimizing the preparation process and for supporting the development of concepts and strategies that aim to increase the efficiency of individual and collective performance [28]. In the field, where one succeeds quickly, the technical skills are highly sought after although they require a continuous reassessment of the game situation, as each game is influenced by the previous games and, in turn, it influences the future games [29].

Among the rules that outline the game of a volleyball game, the rules on rotation, position on the field and rules on the field area stipulate various skills and actions that can be performed depending on the player's position on the field: the attacking area (zones 4, 3, and 2) or the defence zone (zones 1, 6, and 5). Given that some authors [30] have indicated criteria for classifying the rotations according to their importance in competitive volleyball (for example, the position of the coordinator on the field), two stages of the match may be distinguished: a stage in which the coordinator is in the attack zone and one in which he/she is in the defence zone.

Research on volleyball match analysis has lately focused on the importance of team success and failure [31]. Some studies have focused on the area of acquisition associated with its variables, attack and obtaining the point of taking over the service [32].

These studies have shown that fixing the takeover zone determines the quality of the action, both through the correlation between the effectiveness of the reception and the attack zone, as well as through the correlation between the moment and effect of the attack, and the number of players from the blockade. However, these studies do not refer to the variables in relation to the coordinator's position. As the personnel involved in volleyball has become 
multidisciplinary and it increasingly consists of coaches, doctors, nutritionists and psychologists [33], the best training methods can reach all teams and players and, in turn, they can help them turn into more competitive teams.

Previous studies have shown the widespread use of the offensive zone in attacking during volleyball games, often to the detriment of the defense zone [34]. When the coordinator is in the defense zone, he/she usually has five attack options, which makes this area preferable to him/her compared to the attack zone, which has only four attack options. Thus, the attack is undoubtedly the most important component for scoring points and thus proved to be a decisive aspect of the attacking strategy of any volleyball team [35]. Through attacks, teams gain a large percentage of points from the total number of actions, since almost half of all the attacks executed lead to a point [36]. According to other studies, service reception is a factor that greatly influences the organization of the offensive maneuver and which presents a relationship between the quality of the service reception and the success of the team [37]. However, the takeover of the service is dependent on the type of service performed by the opponent.

\section{Aim of the study}

The purpose of the experiment was to analyze the first phase parameters of the volleyball game in the Final Four CEV Champions League for women's volleyball at the volleyball team CSM Volei Alba Blaj. We tried to find out what were the parameters that brought victory in the first match of the semi-finals (against Galatasaray Istanbul won 3-1) and the defeat in the final (against VakifBank Istanbul lost 03 ). With the help of the statistical software, we analyzed the decisive factors comparing each set, so that we were able to identify the parameters that have decisively contributed to the victory or defeat.

\section{Hypothesis of the study}

If in the tactical preparation for the match we use specialized statistical programs on the analysis and interpretation of the volleyball game, then we can obtain vital information about achieving the victory.

\section{Materials and methods}

The venue for our experiment was the gymnasium of the Municipal Sports Club of Alba Blaj Volleyball, where they carry out their training and games in the internal championship CSM Volleyball team Alba Blaj, "Transilvania" Sports Hall in Sibiu where they play their European Cup games CSM Volleyball team Alba Blaj, and Bucharest Multipurpose Hall where the Final Four of the CEV Champions League was held at the women's volleyball 2017-2018 edition.

The subjects of the research were 18 legitimate sportsmen in the season 2017-2018 within the CSM Alba Blaj Volleyball.

Statistical analysis included descriptive statistics elements (mean, median, standard deviation) and elements of inferential statistics. The D'Agostino \& Pearson test was applied to determine the distribution of the analyzed data series. For the comparison of means and medians the t-Student test was applied, for pair data, respectively the Wilcoxon test. The significance threshold chosen for the $p$ value was 0.05 . Statistical analysis was performed using the Graph Pad Prism utility.

We aimed to compare certain parameters that influence the outcome of a match such as: service, and service reception.

\section{Results}

In Table I we have statistically analysed the average of the points from the first three sets comparing each first set of matches 1 and 2, then the second set of matches 1 and 2 and the third set of the two matches. We observed that there is a statistically significant difference between the average SERVE Total values in the 2 matches. The next step was to apply the tStudent test for paired data, $p>0.05$, with which we found that there is no statistically significant difference between the mean values of SERVE Err in the 2 matches.

Analysing the data obtained with the Wilcoxon test, $p>0.05$, we observed that there is no statistically significant difference between the median values of SERVE Ace in the 2 matches.

Using the Wilcoxon test, $p>0.05$, ( $p=0.4324)$, we found out that there is a statistically significant difference between the average reception values of the two matches. The next phase was to analyze the parameter of service reception errors, using the Wilcoxon test, with a $\mathrm{p}>0.05,(\mathrm{p}=0.3862)$ with which we observed that we had a statistically significant difference between the medians of the parameters value of the reception errors in the two games. 
Figure 1. Graphical interpretation of serve differences,

serve error, serve ace between the two matches.

Table 1. Statistical analysis of serve parameters, serve errors and points directly from the serve (ace)

\begin{tabular}{|c|c|c|c|c|c|c|c|c|}
\hline SERVE Total & $\begin{array}{l}1^{\text {st }} \\
\text { Game }\end{array}$ & $\begin{array}{l}2^{\text {nd }} \\
\text { Game }\end{array}$ & SERVE Err & $\begin{array}{l}1^{\text {st }} \\
\text { Game }\end{array}$ & $\begin{array}{l}2^{\text {nd }} \\
\text { Game }\end{array}$ & SERVE Ace & $\begin{array}{l}1^{\text {st }} \\
\text { Game }\end{array}$ & $\begin{array}{l}2^{\text {nd }} \\
\text { Game }\end{array}$ \\
\hline Number of values & 14 & 14 & $\begin{array}{l}\text { Number } \\
\text { values }\end{array}$ & 14 & 14 & Number of values & 14 & 14 \\
\hline Minimum & 0.0 & 0.0 & Minimum & 0.0 & 0.0 & Minimum & 0.0 & 0.0 \\
\hline $25 \%$ Percentile & 0.0 & 0.0 & 25\% Percentile & 0.0 & 0.0 & $25 \%$ Percentile & 0.0 & 0.0 \\
\hline Median & 2.500 & 2.500 & Median & 0.0 & 0.0 & Median & 0.0 & 0.0 \\
\hline 75\% Percentile & 15.50 & 6.250 & 75\% Percentile & 2.000 & 1.000 & 75\% Percentile & 0.250 & 0.0 \\
\hline Maximum & 22.00 & 9.000 & Maximum & 3.000 & 2.000 & Maximum & 4.000 & 2.000 \\
\hline Mean & 6.929 & 3.286 & Mean & 0.643 & 0.429 & Mean & 0.500 & 0.214 \\
\hline Std. Deviation & 8.157 & 3.407 & Std. Deviation & 1.082 & 0.646 & Std. Deviation & 1.160 & 0.579 \\
\hline Std. Error & 2.180 & 0.910 & Std. Error & 0.289 & 0.173 & Std. Error & 0.310 & 0.155 \\
\hline $\begin{array}{l}\text { Lower 95\% CI of } \\
\text { mean }\end{array}$ & 2.219 & 1.319 & $\begin{array}{l}\text { Lower } 95 \% \mathrm{CI} \\
\text { of mean }\end{array}$ & 0.018 & 0.055 & $\begin{array}{l}\text { Lower 95\% CI of } \\
\text { mean }\end{array}$ & -0.17 & -0.12 \\
\hline $\begin{array}{l}\text { Upper 95\% CI of } \\
\text { mean }\end{array}$ & 11.64 & 5.253 & $\begin{array}{l}\text { Upper 95\% CI } \\
\text { of mean }\end{array}$ & 1.267 & 0.802 & $\begin{array}{l}\text { Upper } 95 \% \text { CI of } \\
\text { mean }\end{array}$ & 1.170 & 0.549 \\
\hline $\begin{array}{l}\text { D'Agostino \& Pea } \\
\text { normality test }\end{array}$ & rson & nibus & $\begin{array}{l}\text { D'Agostino \& Pe } \\
\text { normality test }\end{array}$ & son & nnibus & $\begin{array}{l}\text { D'Agostino \& Pea } \\
\text { normality test }\end{array}$ & rson & inibus \\
\hline $\begin{array}{l}\text { Passed normality } \\
\text { test (alpha }=0.05 \text { )? }\end{array}$ & Yes & Yes & $\begin{array}{l}\text { Passed } \\
\text { normality test } \\
(\text { alpha=0.05)? }\end{array}$ & Yes & Yes & $\begin{array}{l}\text { Passed normality } \\
\text { test } \\
\text { (alpha=0.05)? }\end{array}$ & Yes & Yes \\
\hline Sum & 97.00 & 46.00 & Sum & 9.000 & 6.000 & Sum & 7.000 & 3.000 \\
\hline
\end{tabular}



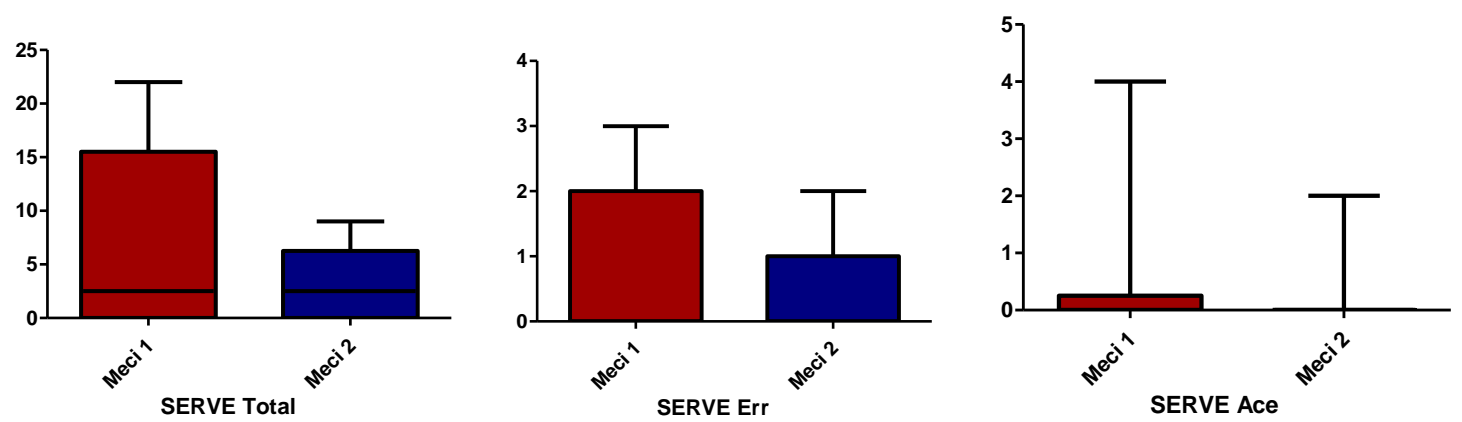

Figure 2. Total serve statistics, serve errors and points directly from the serve

Table 2. Statistical analysis of the total reception parameter and reception errors in both games

\begin{tabular}{|c|c|c|c|c|c|}
\hline RECEPTION Total & $\begin{array}{l}\text { First } \\
\text { Game }\end{array}$ & $\begin{array}{l}\text { Second } \\
\text { Game }\end{array}$ & RECEPTION Err & $\begin{array}{l}\text { First } \\
\text { Game }\end{array}$ & $\begin{array}{c}\text { Second } \\
\text { Game }\end{array}$ \\
\hline Number of values & 14 & 14 & Number of values & 14 & 14 \\
\hline Minimum & 0.0 & 0.0 & Minimum & 0.0 & 0.0 \\
\hline 25\% Percentile & 0.0 & 0.0 & 25\% Percentile & 0.0 & 0.0 \\
\hline Median & 0.0 & 0.500 & Median & 0.0 & 0.0 \\
\hline $75 \%$ Percentile & 7.250 & 6.500 & 75\% Percentile & 1.250 & 1.000 \\
\hline Maximum & 35.00 & 38.00 & Maximum & 6.000 & 2.000 \\
\hline Mean & 5.143 & 4.786 & Mean & 0.785 & 0.500 \\
\hline Std. Deviation & 10.04 & 10.19 & Std. Deviation & 1.672 & 0.769 \\
\hline Std. Error & 2.683 & 2.724 & Std. Error & 0.447 & 0.203 \\
\hline Lower $95 \%$ CI of mean & -0.65 & -1.10 & $\begin{array}{l}\text { Lower } 95 \% \text { CI of } \\
\text { mean }\end{array}$ & -0.18 & 0.061 \\
\hline Upper 95\% CI of mean & 10.94 & 10.67 & $\begin{array}{l}\text { Upper } 95 \% \text { CI of } \\
\text { mean }\end{array}$ & 1.751 & 0.939 \\
\hline D'Agostino \& Pearson & & & D'Agostino \& & & \\
\hline $\begin{array}{l}\text { omnibus normality } \\
\text { test }\end{array}$ & & & $\begin{array}{l}\text { Pearson omnibus } \\
\text { normality test }\end{array}$ & & \\
\hline $\begin{array}{l}\text { Passed normality test } \\
\text { (alpha=0.05)? }\end{array}$ & Yes & Yes & $\begin{array}{l}\text { Passed normality } \\
\text { test (alpha }=0.05 \text { )? }\end{array}$ & Yes & Yes \\
\hline Sum & 72.00 & 67.00 & Sum & 11.00 & 7.000 \\
\hline
\end{tabular}
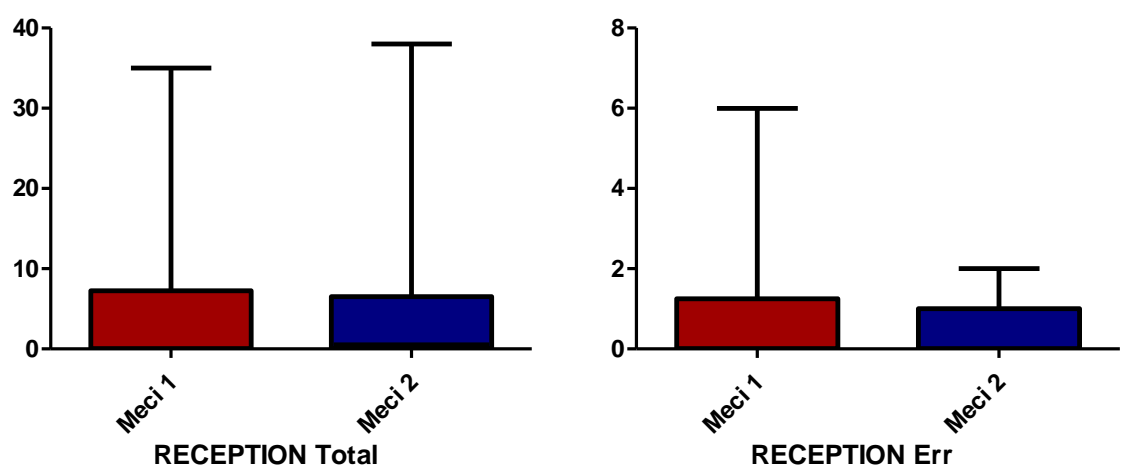

Figure 3. Statistics of the total reception and reception errors of the parameters 


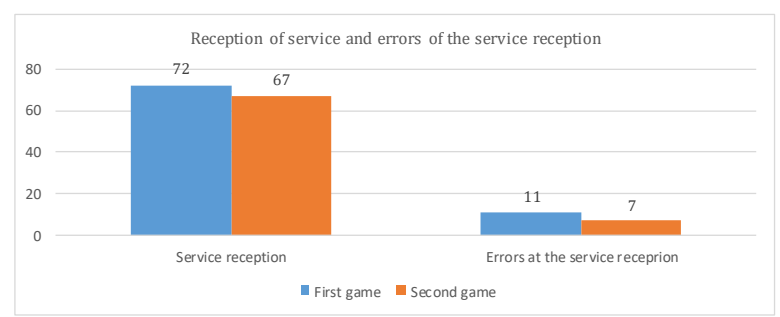

Figure 4. Graphical interpretation of the service reception and service reception errors

\section{Discussions}

Serve and serve reception performance have been identified as predictors of team success in volleyball [38] [39]. Some studies found that higher velocities, lower ball heights when crossing the net, and smaller initial throw angles were the constraints of the serve that distinguished the expert player's serve from the other groups [40].

In our study, we found using the t-Student test for pair data, $p>0.05$, that there is a statistically significant difference between the average values of SERVE Total at the 2 matches, so in the first match the Alba Blaj team managed a number of 97 of good serves compared to only 46 serves in the second match, thus contributing to the failure of the second match.

Reception can be performed by an underhand or by an overhand mode of action. The use of an overhand pass appears to increase the chances of an effective reception [41]. The decision to use one or the other pass seems to be related to serve-related factors as well as the receiver's position and displacement on the court [42 - 44].

Also we found a statistically significant difference with $p>0.05$, between the service reception in both games, with 72 service receptions and 11 errors in the first game compared to 67 service receptions and 7 reception errors in the second.

Other studies found that the odds of an error and an out reception occurring instead of an effective reception, increased with: a higher initial velocity and larger lateral displacement of the serve; receiver's initial position more to the back of the court, larger longitudinal displacement, and larger lateral distance to the target [45].

\section{Conclusions}

After the statistical interpretation of the data we can say that the decisive parameters that contributed to the success of the first match compared to the failure 
of the second match were: the total number of good serves and also the total amount of service receptions and errors at the service reception.

\section{References}

1. Szabo D.A. (2015). Modalities of Using the Information Provided by the Statistical Program Click and Scout for Improving the Outside Hitters' Service Efficiency in Volleyball Game. Future Academy, The European Proceedings of Social \& Behavioral Sciences EpSBS, Volume XV, 341-347.

2. Sopa I.S., Pomohaci M., Achim C. (2018). Testing and developing agility skill in volleyball players aged between 1012 years old, The European Proceedings of Social \& Behavioural Science EpSBS, Future Academy, Vol. LV ICPESK, 628-639.

3. Sheppard J. M., Gabbett T., Tayler K. L., Dorman J., Lebedew, A.J., Borgeaud R. (2007). Development of a repeated-effort test for elite men's volleyball, International Journal of Sports Physiology and Performance, Human Kinetics Inc., No. 2, 292-304.

4. Marques M.C., Van den Tillaar R., Gabbett T.J., Reis,V.M., Gonzalez-Badillo J.J. (2009). Physical fitness qualities of professional volleyball players: Determination of positional differences, Journal of Strength and Conditioning Research, 23 (4), 1106-1111.

5. Szabo D. A. (2014). Improving the offensive efficiency in volleyball game by using a specific statistics software, Discobolul - Physical Education, Sport and Kinetotherapy Journal, Vol. X, 4 (38), 14-17.

6. Palao J. M., Santos J. A., Ureña A. (2004a). Effect of service type and efficacy on block and defense performance in volleyball, RendimientoDeportivo.com, 8, 1-24.

7. Palao J. M. (2004). Effect of game phases and setter position on volleyball performance in competition, Rendimiento Deportivo, 9, 42-52.

8. Palao J. M., Santos J.A., Ureña A. (2004b). Effect of team level on skill performance in volleyball, International Journal of Performance Analysis in Sport, 4 (2), 50-60.

9. Palao J. M., Manzanares P., Ortega E. (2009). Techniques used and efficacy of volleyball skills in relation to gender, International Journal of Performance Analysis in Sport, 9(2), 281-293.

10. https://pdfs.semanticscholar.org/1ec2/2a617fff7544c6604 d54b29213701bb2461b.pdf (accessed on 29 September 2019).

11. Huang C. F., Liu G. C., Sheu T. (2007). Kinematic analysis of volleyball jump topspin and float serve, XXV ISBS Symposium, 333-336.

12. Moras G., Buscà B., Peña J., Rodríguez S., Vallejo L., TousFajardo J., Mujika I. (2008). A comparative study between server mode and speed and its effectiveness in a high-level volleyball tournament, Journal of Sports Medicine and Physical Fitness, 48 (1), 31-36.

13. Tant C.L., Greene B., Bernhardt M. (1993). Three-dimensional kinematic comparison of the volleyball jump serves and the volleyball spike, ISBS - Conference Proceedings Archive, 11 International Symposium on Biomechanics in Sports, 344346.

14. Palao J.M., Valadés D. (2014). Normative profiles for serve speed for the training of the serve and reception in volleyball,
The Sports Journal: Refereed Sports Journal, published by the United States Sports Academy, 2.

15. Hedrick A. (2007). Training for high-level performance in women's collegiate volleyball: Part I training requirements, Strength and Conditioning Journal, 29(6), 50-53.

16. Sheppard J. M., Chapman D. W., Gough C, McGuigan M.R., Newton R.U. (2009b). Twelve-moth training-induced changes in elite international volleyball players, Journal of Strength and Conditioning Research, 23(7), 2096-2101.

17. Gabbett T., Georgieff B. (2007). Physiological and anthropometric characteristics of Australian junior national, state, and novice volleyball players, Journal of Strength and Conditioning Research, 21(3), 902-908.

18. Bird S. P., Tarpenning K. M., Marino F. E. (2005). Designing resistance training programs to enhance muscular fitness: a review of the acute program variables, Sports Medicine, 35(10), 841-51.

19. Teodorescu S., (2009). Periodizare și planificare în sportul de performanță, Editura ALPHA MDM, Buzău. 3.

20. Simion G., Mihăilă I, Stănculescu G., (2011). Antrenament sportiv. Concept sistemic, Editura University Press, Constanța, 118.

21. Szabo D. A. (2016). Modalităţi de valorificare a informaţiilor oferite de programul Click\&Scout în pregătirea echipelor de volei - Divizia A, Teză de doctorat, UNEFS, București, 56.

22. Prisăcaru I. R., (2010). Analiza tacticii şi sistemelor de joc ofensive la echipele de elită din europa în vederea optimizării atacului la echipele româneşti de „top” - handbal masculin, Teză de doctorat, UNEFS, București. 5 .

23. Besi M. (2002). Sections: un program de analiză a imaginii aplicat sportului, B.I. nr. 563-564, București, 23.

24. Popescu D. (2003). Sisteme multimedia, Editura Universităţii din Oradea, 3.

25. Mârza D., (2006). Optimizarea și dirijarea pe baze informatice a pregătirii şi competiţiei în jocurile sportive, Editura PIM, Iaşi. 140.

26. Ionescu M. (2003). Instrucţie şi educaţie. Paradigme, strategii, orientări, modele, Editura Ganunond Srl, Cluj-Napoca, 287.

27. João P., Leite N., Mesquita I., Sampaio J. (2010). Sex difference in discriminative power of volleyball game-related statistics, Perceptual and Motor Skills, 11(3), 893-900.

28. Garganta J. (2009). Trends of tactical performance analysis in team sports: Bridging the gap between research, training and competition, Portuguese Journal of Sports Sciences, 9(1), 8189.

29. Durkovic T., Marelic N., Resetar T. (2008), Influence of position of players in rotation on differences between winning and losing teams in volleyball, International Journal of Performance Analysis in Sport, 8(2), 8-15.

30. Palao J., Ahrab-Fard I. (2011). Side-out success in relation to setter's position on court in women's college volleyball, International Journal of Applied Sports Sciences, 23(1), 155167.

31. Drikos S., Kountouris P., Laios A., Laios, Y. (2009), Correlates of Team Performance in Volleyball, International Journal of Performance Analysis of Sport, Cyncoed, 9(2), 149-156;

32. Amasay T. (2008). Static BlockJump Techniques in Volleyball: Upright Versus Squat Starting Positions, Journal of Strength and Conditioning Research, 22(4), 1242-1248.

33. Valliant M., Emplaincourt H., Wenzel R. (2012). Nutrition education by a registered dietician improves dietary intake 
and nutrition knowledge of a NCAA female volleyball team, Nutrients, 4, 506-516.

34. Ureña A., Calvo R., Lozan C. (2002). A study of serve reception in the top level of Spanish male volleyball after the introduction of the libero player, International Journal of Medicine and science of Physical Activity and Sport, 2, 3949.

35. Miskin M., Fellingham G., Florence L. (2010). Skill Importance in Women's Volleyball, Journal of Quantitative Analysis in Sports, 6(2), 1-14.

36. Patsiaouras A., Moustakidis A., Charitonidis K., Kokaridas D. (2010). Volleyball technical skills as winning and qualification factors during the Olympic Games 2008, International Journal of Performance Analysis in Sport, 10 (2), 115-120.

37. Gubellini L., Lobietti R., Di Michele R. (2005). Statistics in volleyball: the Italian professional's leagues, Scientific Fundaments of Human Movement and Sport Practice, 21(2), 323-334.

38. Peña J., Rodríguez-Guerra J., Buscá B., Serra N. (2013), Which skills and factors better predict winning and losing in highlevel men's volleyball? Journal of Strength and Conditioning Research, 27, 2487-2493.

39. Silva M., Lacerda D., João P. (2014). Game-related volleyball skills that influence victory, Journal of Human Kinetics, 41, 173-179.

40. Deprá P. P., Brenzikofer R. (2008). Comparação de atletas do Voleibol através da análise cinemática e dinâmica de trajectórias de bolas de saque, Journal of Physical Education/UEM, 15, 7-15.

41. Afonso J., Esteves F., Araújo R., Thomas L., Mesquita I. (2012). Tactical determinants of setting zone in elite men's volleyball, Journal of Sport Science in Medicine, 11, 64-70.

42. Miller B. (2005). The Volleyball Handbook. Winning Essentials for Players and Coaches, Champaign, IL: Human Kinetics.

43. Barsingerhorn A. D., Zaal F. T., de Poel H. J., Pepping G. J. (2013). Shaping decisions in volleyball anecological approach to decision-making in volleyball passing, International Journal of Sport Psychology 44, 197-214.

44. Dunphy M., Wilde R. (2014). Volleyball Essentials. Oslo: Total Health Publications, 326.

45. Paulo, A., Fonseca, S., Zaal, F., Araujo, D. (2016). Predicting volleyball serve-reception. Frontiers in Psychology 7:1694 